\title{
Chapter 2 \\ The Interaction Between Intellectual \\ Property Law and Competition Law \\ in the EU: Necessity of Convergent \\ Interpretation with the Principles \\ Established by the Relevant Case Law
}

\author{
Nikolaos E. Zevgolis
}

\section{Introduction}

The fact that the interaction between competition law and intellectual property (IP) law continues to raise new questions and give rise to opportunities for debates is not something novel. However, the European Commission's hope is considered crystal clear: On the one hand to free resources for the proactive estimated value of new policy areas, and on the other hand to secure and guarantee 'the uniform application of European Union's (EU) Competition Law through procedural guidance and economic, effect-based substantive rules'. ${ }^{1}$ This is the reason why the European Commission (EC) does not favor a per se approach regarding this specific issue. ${ }^{2}$ Therefore, it is not incidental that not only market participants but also competition watchdogs have accepted, 'sometimes even fostered', standard setting because of its beneficial effects: inter alia, standardization ensures interoperability of standard-based

\footnotetext{
${ }^{1}$ See Ralf Boscheck, 'Patent Trolls: In Search of Efficient Regulatory Standards' (2016) 39 World Competition 67, 84, quoting: 'This approach is very much in line with the evolution of the EU competition law regime and its shift from centralized authorization to decentralized enforcement through national authorities, courts and undertakings themselves'.

${ }^{2}$ Alexander Italianer, 'The Object of Effects' (CRA Annual Brussels Conference-Economic Developments in Competition Policy, Brussels, 10 December 2014), quoting that: 'there is a clear case law demanding an analysis of effects'.
}

N. E. Zevgolis ( $\square)$

Hellenic Competition Commission, Tutorship cooperation with the Hellenic Open University, Athens, Greece

e-mail: nikoszevgolis@ hotmail.com

(C) The Author(s) 2018

A. Bharadwaj et al. (eds.), Multi-dimensional Approaches Towards New Technology,

https://doi.org/10.1007/978-981-13-1232-8_2 
products, it renders these products more comparable for consumers ${ }^{3}$ and it can help to select the 'best' available technical solution for a given task. ${ }^{4}$ An individual who uses, for instance, a smartphone or a laptop can easily understand the reasons for standardization.

\section{The Adequacy (or Inadequacy?) of the European Commission's Soft Law}

\subsection{Main Provisions in the Horizontal Cooperation Guidelines 2011/C 11/01: The Rule (IPR Are Pro-competitive) and the Exceptions}

IP laws and competition laws share two main targets: promotion of innovation and enhancement of consumer welfare. According to para 269 of the Horizontal Cooperation Guidelines, Intellectual Property Rights (IPRs) 'promote dynamic competition by encouraging undertakings to invest in developing either new or improved products and processes'. This is the reason why IPR are considered 'in general pro-competitive'. 5 Nevertheless, because of IPR, 'a participant holding IPR essential for implementing the standard, ${ }^{6}$ could, in the specific context of

\footnotetext{
${ }^{3}$ European Commission Guidance on the Enforcement Priorities in Applying Article [102 TFEU] to Abusive Exclusionary Conduct by Dominant Undertakings 2009 OJ (C 45) 7-20, para 5:

Consumers benefit from competition through lower prices, better quality and a wider choice of new or improved goods and services. The Commission, therefore, will direct its enforcement to ensuring that markets function properly and that consumers benefit from the efficiency and productivity which result from effective competition between undertakings.
}

\footnotetext{
${ }^{4}$ Peter Picht, 'The ECJ Rules on Standard essential Patents: Thoughts and Issues Post-Huawei' (2016) 37 ECLR 365.

${ }^{5}$ See 'Guidelines on the Applicability of Article 101 of the Treaty on the Functioning of the European Union to Horizontal Co-Operation Agreements' 2011/C 11/01 (Horizontal Cooperation Guidelines), para 269.

${ }^{6}$ para 263 of the Horizontal Cooperation Guidelines:

standards normally increase competition and lower output and sales costs, benefiting economies as a whole. Standards may maintain and enhance quality, provide information and ensure interoperability and compatibility (thus increasing value for consumers).
} 
standard-setting, also acquire control over the use of a standard'. ${ }^{7}$ In cases where 'the standard constitutes a barrier to entry', ${ }^{8}$ Standard Essential Patent (SEP) holder 'could thereby control the product or service market to which the standard relates'. This situation, when it happens, could allow SEP holder to behave in anticompetitive ways: for instance, by 'holding up' users after the adoption of the standard either by refusing to license the necessary IPR or by extracting excessive ${ }^{10}$ royalty fees, it can prevent effective access to the standard. ${ }^{11}$ However, there should not be a misunderstanding: even if the establishment of a standard is in a position to create or increase the market power of IPR holders possessing IPR essential to the

\footnotetext{
${ }^{7}$ Horizontal Cooperation Guidelines (n 5).

8 ibid. About this kind of barrier to entry, the following ought to be underlined: According to Horizontal Cooperation Guidelines (n 5), para 266, in the hypothetical case where 'one technology has been chosen and the standard has been set, competing technologies and companies may face a barrier to entry and may potentially be excluded from the market'. Furthermore, according to the same para, 'standards requiring that a particular technology is used exclusively for a standard or preventing the development of other technologies by obliging the members of the standard setting organization to exclusively use a particular standard, may lead to the same effect. The risk of limitation of innovation is increased if one or more companies are unjustifiably excluded from the standard-setting process'.

${ }^{9}$ Horizontal Cooperation Guidelines (n 5).

${ }^{10}$ However, it ought to be underlined that, in terms of competition law high royalty fees can only be qualified as excessive in case that the pre conditions for an abuse of a dominant position are fulfilled according to Article 102 TFEU and the settled case-law of the Court of Justice of the European Union. See indicatively Case 27/76 United Brands v Commission (1978) ECLI:EU: C:1978:22.

${ }^{11}$ This is the reason why it is acceptable (Horizontal Cooperation Guidelines, para 264) that standard-setting can, in specific circumstances, give rise to restrictive effects on competition by potentially restricting price competition and limiting or controlling production, markets, innovation or technical development. This can happen through three main channels, namely reduction in price competition, foreclosure of innovative technologies and exclusion of, or discrimination against, certain companies by prevention of effective access to the standard. More specifically, standardization may lead to anticompetitive results by preventing certain undertakings from obtaining effective access to the results of the standard-setting process (ie, the specification and/or the essential IPR for implementing the standard). According to Horizontal Cooperation Guidelines, para 268, in the case that 'a company is either completely prevented from obtaining access to the result of the standard or is only granted access on prohibitive or discriminatory terms, there is a risk of an anticompetitive effect'. A contrario, according to the same para:
}

a system where potentially relevant IPR is disclosed up-front may increase the probability of effective access being granted to the standard since it allows the participants to recognize and define which technologies are covered by IPR and which are not. This enables the participants to both factor in the potential effect on the final price of the result of the standard (for instance, choosing a technology without IPR is likely to have a positive effect on the final price) and to verify with the IPR holder whether they would be willing to license if their technology is included in the standard. 
standard, there is no presumption that holding exercising IPR essential to a standard equates to the possession or exercise of market power. ${ }^{12}$ The EC recognizes that the question of market power cannot be answered by per se ruling; a contrario, it can only be assessed on a case-by-case analysis.

\subsection{Preconditions for Pro-competitive Standard-Setting}

\subsubsection{The Central Issue of Access to the Standard}

According to the Horizontal Cooperation Guidelines, ${ }^{13}$ where participation in standard-setting is unrestricted and the procedure for adopting the standard in question is transparent, standardization agreements which contain no obligation to comply with the standard and provide access to the standard on fair, reasonable, and non-discriminatory (FRAND) terms will normally not restrict competition within the meaning of Article 101 para 1 TFEU. At this point, it must be clarified that any standard-setting agreement which makes a discrimination or even distinction against any of either the participating or potential members could have as a result a restriction of competition. For instance, in a case that because of a standard setting organization (SSO) upstream only companies are explicitly excluded (i.e. companies which are not active on the downstream production market), this could lead to an exclusion of potentially better technologies. ${ }^{14}$

Furthermore, para 280 ought to be read in combination with para 293 of the same Guidelines. According to this last paragraph, whether standardization agreements may raise concerns about restrictive effects on competition may depend on whether the members of a SSO remain (or not remain) free to develop alternative standards or products that do not meet the requirements demanded by the agreed

\footnotetext{
${ }^{12}$ At this point it should be underlined that, according to the Guidance on the Commission's enforcement priorities in applying Article 82 of the EC Treaty to abusive exclusionary conduct by dominant undertakings. See Guidance on the Commission's Enforcement Priorities in Applying Article 82 of the EC Treaty to Abusive Exclusionary Conduct by Dominant Undertakings, 2009/C 45/02 (Abusive Exclusionary Conduct):
}

In accordance with the case-law, it is not in itself illegal for an undertaking to be in a dominant position and such a dominant undertaking is entitled to compete on the merits. However, the undertaking concerned has a special responsibility not to allow its conduct to impair genuine undistorted competition on the common market.

\footnotetext{
${ }^{13}$ Horizontal Cooperation Guidelines (n 5), para 280.

${ }^{14}$ ibid, para 297.
} 
standard. ${ }^{15}$ For instance, in case that the standard-setting agreement binds the members to only produce products in compliance with the standard, the risk of a likely negative effect on competition is significantly increased and could in certain circumstances give rise to a restriction of competition by object. ${ }^{16} \mathrm{~A}$ contrario, standards only covering aspects of minor importance or parts of the end-product are considered less likely to give rise to competition concerns than more comprehensive standards.

In addition, the assessment whether the agreement restricts or not competition will also focus on the central issue of access to the standard. In case that the result of a standard (i.e. according to Horizontal Cooperation Guidelines, para 294, the:

specification of how to comply with the standard and, if relevant, the essential IPR for implementing the standard') is not at all accessible, or only accessible on discriminatory terms, for members or third parties (non-members of the relevant standard-setting organization)

This barrier to entry ${ }^{17}$ and/or segmentation 'may discriminate or foreclose or departmentalize markets according to their geographic scope of application and thereby possibly restrict competition'. Nevertheless, 'in the case of several competing standards or in the case of effective competition between the standardized

\footnotetext{
${ }^{15}$ See for example, the Commission Decision in Case IV/29/151 Philips/VCR OJ L 47, 18 February 1978, para 23:

As these standards were for the manufacture of VCR equipment, the parties were obliged to manufacture and distribute only cassettes and recorders conforming to the VCR system licensed by Philips. They were prohibited from changing to manufacturing and distributing other video cassette systems ... This constituted a restriction of competition under Article 85(1)(b).
}

${ }^{16}$ ibid.

${ }^{17}$ Barriers to entry (or expansion) can take various forms. They may be either legal barriers (for example, tariffs or quotas), or they may take the form of advantages specifically enjoyed usually by undertakings with (single) dominant position: for instance, privileged access to essential inputs or natural resources, important technologies. See Case T-30/89 Hilti v Commission [1991] ECR II-1439, para 19. Economies of scale and/or scope, an established distribution and sales network, Case 85/76 Hoffmann-La Roche v Commission [1979] ECR 461, para 48. They may also include costs and other types of hindrance (for example, resulting from network effects, faced by customers in switching to a new supplier). According to the Guidance on the Commission's enforcement priorities in applying Article 82 of the EC Treaty to abusive exclusionary conduct by dominant undertakings:

economies of scale mean that competitors are less likely to enter or stay in the market if the dominant undertaking forecloses a significant part of the relevant market. Similarly, the conduct may allow the dominant undertaking to 'tip' a market characterised by network effects in its favour or to further entrench its position on such a market. Likewise, if entry barriers in the upstream and/or downstream market are significant, this means that it may be costly for competitors to overcome possible foreclosure through vertical integration [...]. 
solution and non-standardized solution, ${ }^{18}$ a case-by-case analysis is demanded: even a limitation of access may not produce restrictive effects on competition. ${ }^{19}$

Supposing that participation in the standard-setting process is open, in the sense that it allows all competitors (active or potential and/or stakeholders) in the market affected by the standard to participate in choosing and elaborating the standard, this will eliminate the risks of a likely restrictive effect on competition by not excluding certain undertakings from the ability and the opportunity to influence the choice and elaboration of the standard. ${ }^{20}$ The greater the likely market impact of the standard, and the wider its potential fields of application, the more important it is to allow equal access to the standard-setting process. However, if the facts of the case show that there is competition between several such standards and SSOs (and not necessarily the same standards are applied by the whole industry) perhaps there will not be any anticompetitive effects. Furthermore, according to Horizontal Cooperation Guidelines, para 295, 'if in the absence of a limitation on the number of participants it would not have been possible to adopt the standard, the agreement would not be likely to lead to any restrictive effect on competition under Article [101 para 1 TFEU]'. Or if the adoption of the standard would have been heavily delayed by an inefficient process, any initial restriction could be counterbalanced by efficiencies which should be considered more significant under Article 101 para 3 TFEU. $^{21}$ According to the same para of the Horizontal Cooperation Guidelines:

[i]n certain situations the potential negative effects of restricted participation may be overcome or at least restricted by ensuring that stakeholders are kept informed and consulted on the work in progress'. ${ }^{22}$ The rule is that 'the more transparent the procedure for adopting the standard, the more likely it is that the adopted standard will take into account the interests of all stakeholders'. ${ }^{23}$

\footnotetext{
${ }^{18}$ Horizontal Cooperation Guidelines (n 5), para 294.

${ }^{19}$ ibid.

${ }^{20}$ In Case IV/31.458 X/Open Group OJ L35, 6 February 1987, para 32: the European Commission considered that even if the standards adopted were made public, the restricted membership policy had the effect of preventing non-members from influencing the results of the work of the group and from getting the know-how and technical understanding relating to the standards which the members were likely to acquire. In addition, non-members could not, in contrast to the members, implement the standard before it was adopted. This is the reason why the agreement was-under these specific circumstances - considered that it constituted a restriction of competition under Article 101 para 1 TFEU.

${ }^{21}$ Nevertheless, it ought to be underlined that the four preconditions for the application of Article 101 para 3 TFEU ought to be concurrent cumulatively.

${ }^{22}$ See Case COMP/39.416 Ship Classification (2010) OJ C2/05.

${ }^{23}$ See Horizontal Cooperation Guidelines (n 5), para 295.
} 


\subsubsection{The Significance of Market Shares of the Goods or Services Based on the Standard}

To assess the effects of a standard-setting agreement, the market shares of the goods or services based on the standard ought to be considered. One of the main problems is that, according to Horizontal Cooperation Guidelines, para 296:

it might not always be possible to assess with a minimum of certainty at an early stage whether the standard will in practice be adopted by a large part of the industry, or whether it will only be used by a very small part of the industry'. Therefore, 'in many cases the relevant market shares of the companies having participated in developing the standard could be used as a sign or indication for assessing the likely market share of the standard; the reason is that the companies participating in setting the standard would in most cases have an interest in implementing the standard. ${ }^{24}$

Nevertheless, according to the same para of the Horizontal Cooperation Guidelines:

as the effectiveness of [standardization] agreements is often proportional to the share of the industry involved in setting and/or applying the standard, high market shares held by the parties in the market or markets affected by the standard will not necessarily lead to the conclusion that the standard is likely to give rise to restrictive effects on competition. ${ }^{25}$

So, a case-by-case analysis is demanded. Market shares provide a useful first indication of the market structure and of the relative importance of the various undertakings active on the market. ${ }^{26}$ However, the EC and the national competition authorities will assess market shares in the light of the relevant market conditions, and the dynamics of the market and of the extent to which there is a product differentiation (if there is such and to which extent there is). In addition, the trend or development of market shares over time may also be considered in volatile markets or in markets where auctions take place. ${ }^{27}$

\footnotetext{
${ }^{24}$ ibid, para 296.

${ }^{25}$ ibid.

${ }^{26}$ Case 85/76 Hoffmann-La Roche \& Co. v Commission [1979] ECR 461, paras 39-41; Case C-62/ 86 AKZO v Commission [1991] ECR I-3359, para 60; Case T-30/89 Hilti v Commission [1991] ECR II-1439, paras 90-92; Case T-340/03 France Télécom v Commission [2007] ECR II-107, para 100.

${ }^{27}$ See Abusive Exclusionary Conduct (n 12), para 13.
} 


\subsubsection{Result of Standardization Agreements}

Standardization agreements frequently create the necessary preconditions for significant static ${ }^{28}$ and dynamic efficiency gains. ${ }^{29}$ For instance, Union wide standards may facilitate market integration ${ }^{30}$ and allow companies to market their goods and services in all Member States, leading on the one hand to increased consumer choice and on the other hand decreasing prices. ${ }^{31}$ More specifically, market integration cannot only be facilitated but also enhanced - the creation of a common market lay at the heart of the EU project, transaction costs can be reduced, the necessary time for innovative products offered to end users can be minimized, interoperability between network and products can be reduced etc. According to the Horizontal Cooperation Guidelines para 308, 'standards which establish technical interoperability and compatibility often encourage competition on the merits between technologies from different enterprises and help prevent lock-into one supplier' ${ }^{32}$ In addition, transaction costs may be reduced due to standards in a very profitable way not only for sellers but also for buyers. For example, standards

\footnotetext{
${ }^{28}$ Both allocative efficiency and productive efficiency constitute the so-called static efficiency. See Massimo Motta, Competition Policy. Theory and Practice (Cambridge University Press 2004) 45-55; Robert H Bork, The Antitrust Paradox: A Policy at War with Itself (New York: Basic Books 1978, reprinted with a new Introduction and Epilogue 1993) 90-91.

${ }^{29}$ See Emanuelson Anna, 'Standardization Agreements in the Context of the New Horizontal Guidelines' (2012) 33 ECLR 69. However, in theory it has also been recognized that:

[w]hen asked to examine a restrictive agreement or a merger, the test to be performed by competition authorities essentially amounts to determining whether the negative effects of the agreement/transaction on competition is more than compensated by 'efficiencies' taking the form of the production of new and/or better products, the realization of economies of scale or scope etc. Such a balancing test will not necessarily be easy as parties to a proceeding will generally try to inflate the 'negative' or 'positive' effects of the agreement/ merger in question.
}

See Damien Geradin, 'Efficiency Claims in EC Competition Law and Sector Specific Regulation' (Comparative Competition Law-Whose Regulation, Which Regulation? Workshop Florence, 12 and 13 November 2004) 1.

${ }^{30}$ Regarding this issue, see indicatively Catherine Barnard, The Substantive Law of the EU: The Four Freedoms (3rd edn, OUP 2010) 14-17.

${ }^{31}$ This point of view is close enough to the point of view of a large part of Post-Chicago school, which considers efficiency as one of the purposes of antitrust, but not the only one. See, for instance, Eleanor M Fox, 'The Modernization of Antitrust: A New Equilibrium' (1981) 66 CORNELL L. REV. 1140, 1152, 1154; Robert Pitofsky, 'The Political Content of Antitrust' (1979) 127 U. PA. L. REV. 1051, 1057. A contrario, 'The fundamental Chicago view is that the pursuit of efficiency, by which is meant allocative efficiency as defined by the market, should be the sole goal of antitrust'. See Alison Jones \& Brenda Sufrin, EC Competition Law (Text, cases and materials) (2nd edn, OUP 2004) 22; Eleanor M Fox and Lawrence A Sullivan, 'AntitrustRetrospective and Prospective: Where Are We Coming From? Where Are We Going?' (1987) 62 New York Univ. LR 936, 956-959.

${ }^{32}$ Horizontal Cooperation Guidelines (n 5), para 308. 
regarding safety, quality or/and environmental aspects of a product (a ship, for instance) may also facilitate consumers' choice and can lead to increased product quality. Furthermore, standards play a significant role for innovation (it is about the so-called dynamic efficiency). According to the Horizontal Cooperation Guidelines paras 308 and 309, these standards:

can reduce the time it takes to bring a new technology to the market and facilitate innovation by allowing undertakings to build on top of agreed solutions. To achieve those efficiency gains in the case of standardization agreements, the information necessary to apply the standard must be effectively available to those potentially wishing to enter the market.

In this regard, the Commission's Decision in Case IV/31.458, X/Open Group is characteristic: 'The Commission considers that the willingness of the Group to make available the results as quickly as possible is an essential element in its decision to grant an exemption'. ${ }^{33}$

It is useful to be clarified that dissemination of a standard may be enforced by marks or logos which certify compliance thereby providing the demanded certainty to customers. However, agreements for testing and certification go beyond the primary objective of defining the standard; this is the reason why they usually constitute a distinct, separate paragraph not only agreement but also market. ${ }^{34}$

From the above-mentioned analysis, it is clear that the effects on innovation ought to be analyzed on a case-by-case basis. Nevertheless, there is rebuttable presumption that standards creating compatibility on a horizontal level between different technology platforms are considered to be likely to give rise to efficiency gains. $^{35}$

\subsection{Main Provisions in the Commission Notice Guidelines on the Application of Article 101 TFEU to Technology Transfer Agreements ${ }^{36}$}

\subsubsection{The Principle of Union Exhaustion}

According to the Commission Notice Guidelines on the Application of Article 101 TFEU to technology transfer agreements, ${ }^{37}$ IP laws give exclusive rights on holders

\footnotetext{
${ }^{33}$ X/Open Group (n 20), para 42.

${ }^{34}$ Horizontal Cooperation Guidelines (n 5), para 310.

${ }^{35}$ See Horizontal Cooperation Guidelines (n 5), para 311.

${ }^{36}$ Commission Notice Guidelines on the Application of Article 101 TFEU to Technology Transfer Agreements, (2014/C 89/03) (Application of Article 101 TFEU to TTA).

${ }^{37}$ ibid, para 5.
} 
of patents, copyrights, design rights, trademarks and other legally protected rights. The owner of IP is protected under IP laws that prevent its unauthorized use and exploitation, for instance, by licensing it to third parties. However, according to the principle of Union exhaustion, ${ }^{38}$ once a product incorporating an IPR, with the exception of performance rights (rental rights are also included ${ }^{39}$ ), has been put on the market inside the European Economic Area (EEA) by the holder or with its approval, the IPR is exhausted in the sense that the holder can no longer use it to control the sale of the product. This principle of Union exhaustion is for instance enclosed in Article 7 para 1 of Directive 2008/95/EC to approximate the laws of the Member States relating to trademarks, ${ }^{40}$ according to its provision, the trademark shall not entitle the proprietor to prohibit its use in relation to goods which have been put on the market in the Union under that trademark by the proprietor or with its approval. The same principle is also enshrined in Article 4 para 2 of Directive 2009/24/EC of the European Parliament and of the Council of 23 April 2009 on the legal protection of computer programs ${ }^{41}$ where there is the provision that the first sale in the Union of a copy of a program by the right holder or with its approval will exhaust the distribution right within the Union of that copy (except for the right to control further rental of the program or a copy thereof). ${ }^{42}$ The holder of an IPR has no right under IP laws to prevent sales by licensees or buyers of such products incorporating the licensed technology. Against the backdrop of this rule, the principle of Union exhaustion is considered compatible with the essential function of IPRs, which is to grant the holder the right to exclude others from exploiting its IP without its consent. ${ }^{43}$

\footnotetext{
${ }^{38}$ It is about one of the main principles in the EU. According to the Court of the European Union:

[...] it must be recalled that the objective of the principle of the exhaustion of the right of distribution of works protected by copyright is, in order to avoid partitioning of markets, to limit restrictions of the distribution of those works to what is necessary to safeguard the specific subject-matter of the intellectual property concerned.
}

See, C-128/11UsedSoft GmbH v Oracle International Corp. [2012] ECR 407, para 62. See also to that effect, Case C-200/96 Metronome Musik [1998] ECR I-1953, para 14; Case C-61/97 FDV [1998] ECR I-5171, para 13; and Case C-403/08 Football Association Premier League and Others [2011] ECR I-9083, para 106.

${ }^{39}$ In this respect, see Case 158/86 Warner Brothers and Metronome Video [1988] ECR 2605; Case C-61/97 Foreningen af danske videogramdistributører [1998] ECR I-5171.

${ }^{40}$ OJ L 299, 8 November 2008, para 25.

${ }^{41}$ OJ L 111, 5 May 2009, para 16.

${ }^{42}$ See in this respect UsedSoft GmbH (n 38).

${ }^{43}$ Application of Article 101 TFEU to TTA, para 6. 


\subsubsection{No Immunity from Competition Law Intervention}

In general, it is acceptable that IP laws grant exclusive rights of exploitation. ${ }^{44}$ Nevertheless, this fact does not entail that IPRs enjoy a kind of immunity from competition law intervention. The application of Article 101 TFEU is possible regarding agreements whereby the holder licenses another undertaking to exploit its IPRs. ${ }^{45}$ 'Nor does it imply that there is an inherent conflict between IPRs and the Union competition rules'. ${ }^{46}$ In reality, both bodies of law have the same twofold basic objective: on the one hand promoting consumer welfare and on the other hand an efficient allocation of resources. Innovation constitutes perhaps the most essential and dynamic component of an open and competitive market economy. Dynamic competition is promoted by IPRs, since undertakings are encouraged to invest in developing new or improved products and processes. Competition is the main factor that creates conditions of pressure on undertakings to innovate. This is the reason why, both IPRs and competition are important for promoting innovation and ensuring a competitive exploitation thereof.

For the assessment of license agreements under Article 101 TFEU it must be kept in mind that the creation of IPRs often requires substantial investment, and that all rarely constitutes a risky effort with serious sunk costs. In order not to reduce dynamic competition and to maintain the incentive to innovate, the innovator must not be improperly restricted regarding the exploitation of IPRs that turn out to be valuable. For the abovementioned reasons the innovator ought to be free to seek appropriate financial remuneration for successful projects which is sufficient to maintain investment incentives, taking also failed projects into account. Furthermore, technology rights licensing may require the licensee to make significant sunk costs in the licensed technology and production assets necessary to exploit it. Sunk costs mean that in case that the licensee leaves that particular field of activity, the investment cannot be used by the licensee for other activities or sold other than at a significant loss. Article 101 TFEU cannot be applied without taking into account such ex-ante investments made by the parties and the risks relating to it. The risk that the parties face and the sunk cost that ought to be committed may thus lead to the agreement falling outside the scope of Article 101 para 1 TFEU or fulfilling the conditions of Article 101 para 3 TFEU, as the case may be, for the period of time required to recover the investment.

\footnotetext{
${ }^{44}$ At this point, a necessary clarification ought to be made: in US antitrust law, monopolization constitutes an offense. On the contrary, under EU competition law, monopolization does not constitute an offense. 'The plain language of Article [102 TFEU] makes it clear that it only prohibits abuses of a dominant position. Thus, Article [102 TFEU] does not condemn conduct aimed at acquiring market power and leading to the creation of a dominant position, even if such conduct is successful.' See Geradin Damien, 'Pricing Abuses by Essential Patent Holders in a Standard-Setting Context: A View from Europe' (2009-2010) 76 Antitrust LJ 329, 346.

${ }^{45}$ See for instance Joined Cases 56/64 and 58/64 Consten and Grundig [1966] ECR 429.

${ }^{46}$ Application of Article 101 TFEU to TTA, para 7.
} 
According to the Commission Notice Guidelines on the Application of Article 101 TFEU to technology transfer agreements, ${ }^{47}$ in assessing licensing agreements under Article 101 TFEU, 'the existing analytical framework is sufficiently flexible to take due account of the dynamic aspects of technology rights licensing'. A presumption that IPRs and license agreements as such give rise to competition concerns simply does not exist. More specifically, 'most license agreements do not restrict competition and create pro-competitive efficiencies'. ${ }^{48}$ The truth is that licensing as such is pro-competitive, because it leads to dissemination of technology and promotes innovation by the licensor and the licensee(s). Furthermore, license agreements that restrict competition may often give rise to pro-competitive efficiencies, which must be assessed under Article 101 para 3 TFEU and balanced against the negative effects on competition. ${ }^{49}$ This is the reason why the great majority of license agreements are compatible with Article 101 TFEU.

\subsection{The Necessity of Considering the Guidance in Applying Article [102 TFEU] to Abusive Exclusionary Conduct by Dominant Undertakings ${ }^{50}$}

Both the above-mentioned Guidelines (about Horizontal Cooperation and Technology Transfer) ought to be read and analysed together with the content of the Guidance in Applying Article [102 TFEU] to Abusive Exclusionary Conduct by Dominant Undertakings. According to this last Guidance about abuse of dominance, the (basic) aim of the Commission's enforcement activity is to ensure that dominant undertakings do not impair effective competition by foreclosing their competitors in an anticompetitive way.

\footnotetext{
${ }^{47}$ ibid, para 9.

48 ibid.

${ }^{49}$ Commission Guidelines on the Application of Article 81(3) of the Treaty, OJ C 101, 27 April 2004, 97. See also Geradin (n 1), quoting the following:
}

When asked to examine a restrictive agreement or a merger, the test to be performed by competition authorities essentially amounts to determining whether the negative effects of the agreement/transaction on competition is more than compensated by 'efficiencies' taking the form of the production of new and/or better products, the realization of economies of scale or scope etc. Such a balancing test will not necessarily be easy as parties to a proceeding will generally try to inflate the 'negative' or 'positive' effects of the agreement/ merger in question.

${ }^{50}$ Abusive Exclusionary Conduct (n 12), 7-20. 
However, according to the Guidance in Applying Article [102 TFEU] to Abusive Exclusionary Conduct by Dominant Undertakings, para 7:

conduct which is directly exploitative of consumers, for example charging excessively high prices or including certain behavior that undermines the efforts to achieve an integrated internal market, is also liable to infringe Article [102 TFEU]. The Commission may decide to intervene in relation to such conduct, where the protection of consumers and the proper functioning of the internal market cannot otherwise be adequately ensured.

\section{The Dynamic Relationship Between Antitrust Law and Intellectual Property Law $^{51}$}

\subsection{The US and EU Convergence Regarding the Exercise of SEPS}

The above-mentioned provisions show that the relationship between antitrust and IP law is 'law in the making', which means that it is not something static; on the contrary it is about something dynamic. In the Information and Communications Technologies (ICT) industry, the exercise of SEPs constitutes the area where the most recent developments are observed.

Furthermore, it ought to be underlined that US and EU authorities finally have reached similar positions on the main principles governing the solution to questions raised by the exercise of SEPs, despite the fact they started from different legal positions. ${ }^{52}$ The truth is that several issues remain open. Courts and competition regulators from both sides of the Atlantic have already set out guidance to the patent holders and potential licensees with such a level of clarity that should enable them to reach agreed solutions and further reduce the risks of patent hold-up or patent hold-out. In EU, the principles have been set out by courts (i.e. settled or established case law). Further, (self-binding) guidelines laid by competition regulators/

\footnotetext{
${ }^{51}$ See relatively Jean-Yves Art, 'Competition and Intellectual Property: Friends or Foes-The Case of SEPs' in Raffaelli (ed), Antitrust Between EU Law and National Law (Brussels/Milan 2015) 190.

${ }^{52}$ ibid.
} 
watchdogs, ${ }^{53}$ has enabled both patent holders and potential licensees to achieve workable solutions and further reduce the above-mentioned risks. ${ }^{54}$

\subsection{The Commission's Practice: The Motorola and Samsung Decisions as Basic Examples}

Regarding SEPs, in 2014 the Commission adopted two decisions. The Motorola ${ }^{55}$ and Samsung ${ }^{56}$ decisions outlined that there should be some limits to SEP rights precisely because of the competition context in which the standardization process takes place. The Commission was able to act not only quickly but also effectively in both cases on a general issue which had broader market relevance. ${ }^{57}$

Regarding Samsung, the Commission accepted binding commitments that Samsung will not seek injunctions ${ }^{58}$ against Apple in relation to SEPs where certain

\footnotetext{
${ }^{53}$ At this point, it must be clarified that the courts decisions constitute the so-called case law. The EC's decisions do not constitute case law; they constitute the Commission's practice. The guidelines constitute the so-called soft law. However, the guidelines suffer from the disadvantage of being nonbinding 'and the EU institutions may change their minds on particular issues or some issues may arise for the first time with all the attendant uncertainty'. See indicatively Vincent JG Power, 'European Union State Aid Law and Ports, in Philip Wareham (ed) Competition Law and Shipping: The EMLO Guide to EU Competition Law in the Shipping and Port Industries (CMP Publishing 2010) 269.

${ }^{54}$ As Niels Ersboll, 'Information exchange between Competitors' in Philip Wareham (ed) Competition Law and Shipping: The EMLO Guide to EU Competition Law in the Shipping and Port Industries (CMP Publishing 2010) 67:
}

EU Competition Law on information exchange between competitors has been developed through the case law of the European Courts and the European Commission decisional practice. However, the case law is sporadic and the judgements and decisions are often highly case specific, which makes them difficult to apply across the board.

\footnotetext{
${ }^{55}$ Case AT.39985 Motorola-Enforcement of GPRS SEPs, paras 311, 322, 377, 415-420.

${ }^{56}$ Case AT.39939 Samsung Electronics-Enforcement of UMTS SEPS (2014) OJ C 350/8, para 62.

${ }^{57}$ Jorg Witting and Peter Willis, 'European Commission closes Samsung and Motorola cases on alleged abuse of standard essential patents' (Bird \& Bird, 7 May 2014) <https://www.twobirds. $\mathrm{com} / \mathrm{en} / \mathrm{news} /$ articles/2014/global/commission-closes-samsung-and-motorola-cases-on-allegedabuse-of-standard-essential-patents> accessed 25 October 2017.

${ }^{58}$ European Commission 'Antitrust Decisions on SEPs (SEPs)—Motorola Mobility and Samsung Electronics-Frequently Asked Questions' (MEMO 29 April 2014), states that:
}

An injunction is a court order aimed at preventing the continuation of a patent infringement. Generally, it includes the prohibition to sell the product infringing the patent. Such injunctions can be preliminary - as a precautionary measure typically for the time of the assessment of the case on the merits by the court. Injunctions can also be permanent as a result of the decision on the merits by a court. 
conditions are met. Regarding Motorola, the Commission found that this company had infringed Article 102 TFEU by seeking and enforcing injunctions against Apple in relation to SEPs. The Commission emphasized the importance of protecting IPRs and highlighted the exceptional nature of its intervention in these two cases, reflecting the fact that the use of technology covered by SEPs is essential for entry into certain markets.

At this point it ought to be underlined that although both the Samsung and Motorola cases concerned patents essential to mobile telecommunications standards, and the decision of the Commission in both cases has the intention of establishing more general principles, applicable to all SEPS that are crucial for the assurance of interoperability across not only the communications and IT sectors, but also more widely in sectors, like, for example, the maritime transports sector, the automotive sector ${ }^{59}$ and the renewable energy, which are also characterized by innovation and standardization.

In the above-mentioned cases, the behavior of Motorola and the behavior of Samsung were considered abusive by the Commission for the following main reasons: first of all, because they could result in a temporary ban on online sales of Apple mobile products, secondly, because they could force Apple into accepting disadvantageous terms as the price of settlement, and finally because they could cause harm to the standard development process.

So, in few words, the purpose/effect of the settlement was that Apple's continued (and constant) presence in the market ought to be ensured. However, it is remarkable that the final solution that the EC decided in these two cases as preferable was the acceptance of binding commitments instead of the ascertainment of abusive exploitation of a dominant position and the imposition of a high fine to each company. Consequently, a very careful approach by the Commission is detected and endorsed, which shows that the peculiarities of the Motorola and Samsung cases were correctly recognized and considered as the crucial reason for the special treatment of both companies. After the Motorola and Samsung cases, an interesting development in European case law took place.

\footnotetext{
${ }^{59}$ Regarding this specific sector, see Shervin Pishevar, 'Is Standardization for Autonomous Cars Around the Corner?' (CPI, 2017) <https://www.competitionpolicyinternational.com/wp-content/ uploads/2017/11/9652873_2_Autonomous-Auto-Standardization-shortened.pdf>.
} 


\subsection{Did the European Case Law Follow the Commission's Approach?}

\subsubsection{Assessment of the Case Huawei/ZTE (C-170/2013) and Criticism ${ }^{60}$}

In the Huawei $v$ ZTE ruling the Court of Justice of the European Union (CJEU) confirmed not only according to the Commission's point of view, ${ }^{61}$ but also according to a significant part of theory, ${ }^{62}$ the position of the Commission in the Motorola and Samsung cases on two main points. The first, that SEPs are different from other patents because of the commitments to license on FRAND terms, and the second is that in cases where there is a company willing to take a license on FRAND terms, 'injunctions should be off the table'. ${ }^{63}$

However, even if the judgement of the CJEU does partially or indirectly confirm the EC's approach to the same issues in the Motorola and Samsung cases, its approach is considered narrower, ${ }^{64}$ which means that there are still unresolved issues. ${ }^{65}$ Furthermore, there is a part in theory which gives the impression that it even more severe against the Commission's approach in the Motorola and Samsung cases, ${ }^{66}$ considering that even before the Huawei/ZTE judgement, it was doubtful whether the Commission's actions in the Motorola and Samsung cases were consistent with its own enforcement guidance (about the application of Article [102

\footnotetext{
${ }^{60}$ See indicatively, Björn Lundqvist, 'The Interface between EU Competition Law and SEPsfrom Orange-Book-Standard to the Huawei Case' (2015) 11 ECJ 367, 368.

${ }^{61}$ See also Commissioner Vestager, 'Intellectual Property and Competition' (19th IBA Competition Conference, Florence, 11 September 2015) <https://ec.europa.eu/commission/ commissioners/2014-2019/vestager/announcements/intellectual-property-and-competition_en>.

${ }^{62}$ 'Huawei (indirectly) confirms the previous practice of the European Commission'. See Andreas Heinemann, 'Standard Essential Patents in Standard Setting Organizations: Competition Law and the Realization of Licensing Commitments' (2015) 10 JIPLP 947, 950.

${ }^{63}$ The CJEU placed remarkable emphasis 'on the finding that actions for patent infringement are not in breach of Article 102 TFEU provided certain requirements are met'. See Heinemann (n 62) 950.

${ }^{64}$ ' $[\mathrm{M}]$ ore in line with that established in the CJEU's so-called essential facilities case law'. See Sean-Paul Brankin, Salome Cisnal de Ugarte and Lisa Kimmel, 'Huawei: Injunctions and SEPsIs Exclusion a Foregone Conclusion?' (2015-2016) 30(1) Antitrust 80; See also, Peter Picht quotes in a literary way that 'the ECJ's 'middle path' needs to get broader and more discernible in order not to become a slippery slope'. Peter (n 4) 375.

${ }^{65}$ See Sean-Paul Brankin, Salome Cisnal de Ugarte and Lisa Kimmel, 'Huawei/ZTE: Towards a More Demanding Standard of Abuse in Essential Patent Cases' (2016) 7 JECLAP 520. See also Lundqvist (n 60) 389, 391, who quotes that ' $[\mathrm{t}]$ he ECJ, by drafting the procedure so narrowly, strongly encourages the parties to settle the dispute quickly'.

${ }^{66}$ See Brankin (n 64).
} 
TFEU]). For the reasons that were analyzed above in 2.4 of this chapter, ${ }^{67}$ this approach may be considered as undue; the self-binding Guidance of the Commission in Applying Article [102 TFEU] to Abusive Exclusionary Conduct by Dominant Undertakings cannot be interpreted in such a narrow sense, according to which, the intervention of the Commission would be excused only in cases of anticompetitive foreclosure of competitors. In such a scenario, excessive pricing cases, for instance, would be excluded from the Commission's abuse of dominance 'radar'. ${ }^{6}$

More specifically, according to para 42 of the Huawei $v$ ZTE judgement: '[t]he court must strike a balance between maintaining free competition [...] and the requirement to safeguard that proprietor's IPRs and its right to effective judicial protection'. The court should strike not just a balance, but also the right balance. So, the honest effort made to establish a fair balance between patent law and competition law is demonstrated by the CJEU in the Huawei $v$ ZTE case. $^{69}$

Perhaps, there is some doubt about the CJEU's intent with regard to the higher foreclosure standard in Magill and the so-called essential facilities cases that followed on from Magill by the statement earlier in the CJEU's judgement that 'it

\footnotetext{
${ }^{67}$ See Abusive Exclusionary Conduct (n 12), para 7.

${ }^{68}$ Regarding this issue, see 'The Right Price for Intellectual Property Rights: The Debate Continues' (Oxera, October 2017). See also the Case C-177/16 AKKA/LAA v Konkurences padome ECLI:EU:C:2017: 689. In this case the CEU (ex ECJ) concluded-amongst others - the following:
}

1. Trade between Member States is capable of being affected by the level of rates set by a copyright management organisation that holds a monopoly and also manages the rights of foreign copyright holders, with the result that Article 102 TFEU may be applicable.

2. For the purposes of examining whether a copyright management organisation applies unfair prices within the meaning of point (a) of the second paragraph of Article 102 TFEU, it is appropriate to compare its rates with those applicable in neighbouring Member States as well as with those applicable in other Member States adjusted in accordance with the PPP index, provided that the reference Member States have been selected in accordance with objective, appropriate and verifiable criteria and that the comparisons are made on a consistent basis. It is permissible to compare the rates charged in one or several specific user segments if there are indications that the excessive nature of the fees affects those segments.

3. The difference between the rates compared must be regarded as appreciable if that difference is significant and persistent. Such a difference is indicative of abuse of a dominant position and it is for the copyright management organisation holding a dominant position to show that its prices are fair by reference to objective factors that have an impact on management expenses or the remuneration of right holders.

${ }^{69}$ Paras 42, 52, 53 and 73 are considered as crucial paragraphs of the decision Huawei $v$ ZTE. However, according to Brankin and others para 73 is a key paragraph. It should be mentioned that in this paragraph the CJEU expressly adopted a narrower, and exclusionary, analysis of abuse. Brankin (n 64), para 73. 
must be pointed out, as the Advocate General has observed in point 70 of his Opinion, that the particular circumstances of the case in the main proceedings distinguish that case from [the Magill case law]'. ${ }^{70}$ Nevertheless, the CJEU had no real intention of distinguishing these cases completely. In para 70 of his Opinion, to which the CJEU refers, AG Wathelet expressly stated that the Magill case law remains 'partially relevant'. In this context, it must be acceptable that, as in the refusal to supply cases, SEP cases involve — as the CJEU specifically recognized - a delicate balancing of competing rights and interests. As Andreas Heinemann pointed out correctly in his final remarks,

[t]he Huawei judgement of the CJEU provides new guidance for the relationship between intellectual property law and competition law. It clarifies that a solution conducive to innovation cannot be achieved by protecting intellectual property rights against competition law, but, rather, only by embracing the complementary nature of both areas of law. ${ }^{71}$

\subsubsection{Results and Consequences of the CJEU's Decision in Huawei/ ZTE Case}

The success story of the Huawei v ZTE judgement is constituted on successfully balancing the bargaining powers between owners of so-called 'SEP owners' and producers of smart phones and other telecommunications devices relying upon these patents. As Torsten Körber quoted:

[t]he ECJ's judgement in Huawei $v$ ZTE marked the outcome of an important battle in the so-called 'patent wars' between the makers of smart phones and other telecommunications equipment. In its judgement, the ECJ balanced the bargaining powers between owners of so-called 'standard essential patents' ('SEP owners') and makers of smart phones and other telecommunications devices relying upon these patents ('makers'). ${ }^{72}$

The truth is that the CJEU in its Huawei v ZTE was extremely prudent and made very careful steps. However, the potential consequence of the ECJ's judgement in Huawei $v$ ZTE is that in the future, SEP owners who bring abusive actions against good faith licensees cannot count on a lack of severity because the European Court of

\footnotetext{
${ }^{70}$ Case C-170/13 Huawei Technologies Co. Ltd v ZTE Corp. EU:C:2015:477, para 48.

${ }^{71}$ Heinemann (n 62) 952.

${ }^{72}$ Torsten Körber, 'Abuse of a Dominant Position by Legal Actions of Owners of Standard essential Patents: Huawei Technologies Co. Ltd v ZTE Corp.' (2016) 53 CML Rev. 1107.
} 
Justice (ECJ) has already clarified the SEP owners' obligations under Article 102 TFEU in this specific judgement of preliminary ruling, according to Article 267 TFEU. In any case, the CJEU decision in the Huawei $v$ ZTE case constitutes a 'roadmap' for FRAND cases. ${ }^{73}$

\subsubsection{Unanswered Questions}

The CJEU did not answer the question whether SEP owners enjoy a dominant position per se, despite the fact that the Advocate General (Melchior Wathelet) had questioned a per se assumption. ${ }^{74}$ Nevertheless, according to a rebuttable presumption, in practice SEP owners are almost always dominant.

The CJEU based the licensing obligation of the SEP owner (as well as the compulsory licensing defense of the alleged infringer) on both Article 102 TFEU and the FRAND commitment. This leaves room for the question whether the Huawei $v$ ZTE decision also applies to cases in which the SEP owner is not bound by a FRAND commitment (for example, in the case that the SEP owner has acquired the SEP from the original owner without submitting to the FRAND commitment). It is doubtful whether the answer to this question could be affirmative. ${ }^{75}$ Perhaps, this will be one of the issues that the forthcoming Guidelines prepared by the EC are going to clarify. ${ }^{76}$

The CJEU distinguished the facts of the Huawei $v$ ZTE case (a SEP situation) from those of the German Orange Book-Standard case (non-SEP situation). So, a crucial question is whether the test applied in Huawei $v$ ZTE case can still be applied to non-SEP cases. Making use of the teachings of a de facto standard (like in the German case) can be as indispensable for market access as making use of a SEP (like in the Huawei $v$ ZTE case). If the requirements of the Magill decision ${ }^{77}$

\footnotetext{
${ }^{73}$ Heinemann (n 62).

${ }^{74}$ Advocate General's Opinion in Huawei Technologies (n 70), paras 57-58.

${ }^{75}$ According to Hanns Ullrich 'FRAND terms are not a single, uniform set, but a framework providing for a range'. Hanns Ullrich 'FRAND Access to Open Standards and the Patent Exclusivity: Restating the Principles' (Concurrences No. 2, 2017) para 44.

${ }^{76}$ See the last part of this chapter.

${ }^{77}$ Joined Cases C-241/91 P \& C-242/91 P Radio Telefis Eireann (RTE) \& Independent Television Publication Ltd (ITP) v Commission [1995] ECR I-743, [1995] 4 CMLR 718, [1995] 1 CEC 400. For instance, in the Magill case the ECJ stated that: 'the refusal by the owner of an exclusive right to grant a licence, even if it is an act of an undertaking holding a dominant position, cannot in itself be abuse of a dominant position'. Nevertheless, the ECJ pointed out that 'the exercise of an exclusive right by the proprietor may, in exceptional circumstances, involve abusive conduct'. Such exceptional circumstances may occur where the refusal to license cannot be objectively justified and would eliminate all competition in a downstream market for a new product not offered by the owner of the IPR for which there is customer demand. See George Karydis and Nikolaos Zevgolis, 'Regulation 1400/2002 and Access to Technical Information: Necessity of Convergent Interpretation With the Principles Established by the Relevant Case Law' 2009) 30 ECLR 95, 100,
} 
are fulfilled, the owner of an indispensable IPR (either it is a SEP or a non-essential patent) is under a licensing obligation due to Article 102 TFEU. Hence, in principle, the same rules (i.e. the Huawei $v$ ZTE test) could be applied.

The CJEU did not clarify the meaning of 'FRAND'. The court left this task to the parties which may request the help of a court or an arbitration panel. This appears to be correct in principle, because general rules regarding the very diverse and dynamic telecommunications sector, for example, is not realistic to find. ${ }^{78}$ This is the reason why the author's hope is that this issue will not be one of the issues that the forthcoming Guidelines prepared by the EC are going to clarify. ${ }^{79}$

It ought to be mentioned that some lower German patent courts seem to somehow ignore the CJEU's Huawei v ZTE decision; these courts still seem to be somewhat reluctant to rethink their traditional lines of reasoning (which are IPR-holder friendly). ${ }^{80}$ Nevertheless, according to Regulation 1/2003, the national courts are bound by the ECJ's interpretation of Article 102 TFEU (and Article 101 TFEU).

\section{Conclusion: The Forthcoming Guidance-Should We Expect Undesirable Surprises?}

Everybody who is involved in the issue about the interaction between IP Law and Competition Law accepts that consumers must gain access to a wide range of innovative and creative goods and services at reasonable prices. The relevant - and mainly the recent - case law, seems that it satisfies the need for predictability. In any case, the undisputable truth is that competition policy and IP policy ought to 'work hand in glove in order to promote economic growth'. ${ }^{81}$

Due to the Huawei $v$ ZTE judgement, the successful effort made by the CJEU to establish a fair balance between patent law and competition law is demonstrated with emphasis. It is characteristic and indicative that in Japan, for example, the specific judgement was used in order to create relevant Guidelines. ${ }^{82}$ However, in

quoting that '[...] it should be underlined that, according to the ECJ's judgement in its Magill decision (para 34), as regards the application of Article 82 in the case of a refusal to deal, intellectual property rights ought to be treated in a different way from other property rights'.

${ }^{78}$ Art (n 51) 185.

${ }^{79}$ See the last part of this chapter.

${ }^{80}$ Korber (n 72) 1110.

${ }^{81}$ Commissioner Vestager, 'Intellectual Property and Competition' (19th IBA Competition Conference, Florence, 11 September 2015).

${ }^{82}$ Toshiaki Takigawa, 'Antitrust Perspectives from Japan' (2nd International Conference on Standardization, Patents and Competition Issues: Perspectives from Asia Pacific region and Europe, New Delhi, 10 and 11 June 2017). 
April 2017, the Commission indicated it might publish a formal policy document in order to clarify the rules on patent ownership and licensing. Any guidance by the Commission ought to build on the Huawei $v$ ZTE judgement and must not undermine it.

According to unconfirmed information, an EU 'guidance' document on how companies can manage the licensing of technology to connect devices to the internet was expected before the end of 2017. It would be about a document that would try to balance the interests of companies that license patents (for example, Ericsson, Nokia and Qualcomm) with those that use the patents to create Internet-connected products. 'There have been ongoing debates on all different kind of levels on how to strike a balance between providers and implementers, to ensure that all sides feel there is a level playing field where certain basic rules are shared'. ${ }^{83}$ However, the publication of the Commission's Notice (or Guidelines?) has already been delayed for several reasons because there were different views in the Commission itself, i.e. between the internal divisions involved. Furthermore, there was a significant interest and reaction from the industry, which was concerned that its point of view was not sufficiently considered. Opposing interests are present in the case examined: the undisputable truth is that patent owners are seeking to continue the current licensing model, 'which allows them to license to the 'end user,' such as smartphone makers' ${ }^{84}$ On the other hand, device manufacturers have the intention of accessing 5G technology through components set inside their products, without being obliged to license the technology. One of the Commission's main concerns is that the next generation of technology ought to be available also for small and medium-sized enterprises (SMEs). This is the challenge that the Commission faces: the diffusion of technology should really take place throughout the value chain. For now, unfortunately it seems that SMEs are not able to really find their way, without the Commission's help. However, in general, the European policy about the SMEs is considered quite protective. Therefore, in combination with the 'rulings' by the ECJ in its Huawei v ZTE judgement and also several competition cases involving SEPs, it is considered that 'a certain 'holistic' vision', constitutes a desideratum in the debate in process over licensing. ${ }^{85}$ The good news is that the waters are not unchartered, the already existing case law combined with the relevant soft law and practice created by the EC simply confirms this point.

Acknowledgements Many thanks to Danielle Apostolatos for her comments. This paper is dedicated to the memory of my uncle and my daughter's godfather, Totomis Protonotarios (19562016).

\footnotetext{
${ }^{83}$ See Matthew Newman, 'EU IP Document Will Balance Interests of Tech Companies With Those of License Holders' (Mlex Market Insight, 25 September 2017).

${ }^{84}$ ibid.

${ }^{85}$ Antti Peltomäki stated that 'If we are able to tie the knots, and if we are able to give a certain kind of map and tools for you to play, then we've done our job'. Antti Peltomäki, 'Keynote Address' (LeadershIP EU, Brussels, 25 September 2017).
} 
Disclosure All views and legal opinions expressed in this paper are strictly personal and do not reflect the point of view of the Hellenic Competition Commission.

Open Access This chapter is licensed under the terms of the Creative Commons Attribution 4.0 International License (http://creativecommons.org/licenses/by/4.0/), which permits use, sharing, adaptation, distribution and reproduction in any medium or format, as long as you give appropriate credit to the original author(s) and the source, provide a link to the Creative Commons license and indicate if changes were made.

The images or other third party material in this chapter are included in the chapter's Creative Commons license, unless indicated otherwise in a credit line to the material. If material is not included in the chapter's Creative Commons license and your intended use is not permitted by statutory regulation or exceeds the permitted use, you will need to obtain permission directly from the copyright holder.

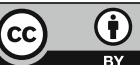

